\title{
Rapid methods for determining tanier (Xanthosoma spp.) root responses to soil acidity'
}

\author{
K. Dale Ritchey," Lucas V. Ramírez," Ricardo Goenaga" \\ and Victor Chew
}

\begin{abstract}
Three methods for evaluating differences in root tolerance to soil acidity were tested on tanier (Xanthosoma spp.) varieties Alela and Vinola. In each method, tanier root growth responded significantly to calcium hydroxide application to a Maricao elay initially at $68 \% \mathrm{Al}$ saturation. In the most efficient method, sections of tanier corms were grown 5 weeks in Pro-Mix in $8.7 \mathrm{~cm}$ diameter plastic cups. These "inserts" were removed from the plastic cups and placed in the center of $20-\mathrm{cm}$ pots in contact with 3 pie-shaped sections of soil which had exchangeable aluminum contents of 10,4 , and 0 meq/100g prepared by the addition of $0,6.7$ or 20 meq $/ 100 \mathrm{~g}$ lime, respectively. The soils were in separate plastic bags open in the center so that roots from the insert could grow into any or all soils. In the other two methods, either inserts or plants grown in sand beds were placed in pots treated with only one lime level each. After 18 days of growth, the roots which had penetrated into each soil were cut off and separated by size. Root growth was greatest in the soil treatment with 6.7 meq/100 g lime, and least in the treatments with 0 or $20 \mathrm{meq} / 100 \mathrm{~g}$ lime. Diminished growth in the latter was apparently due to over-liming since pH reached 6.9. There was no clear difference in lime response between the two varieties tested. Coefficients of variation ranged from 34 to $73 \%$.
\end{abstract}

\section{RESUMEN}

Métodos para determinar rápidamente la tolerancia de raíces de yautía (Xanthosoma spp.) a la acidez del suelo

Se estableció un experimento para evaluar tres métodos rápidos que puedan usarse para seleccionar variedades de yautía resistentes a la acidez del suelo. En el método mós eficaz, se colocaron secciones de semilla en varios envases plásticos con Pro-Mix. Después de cinco semanas la semilla germinada se sacó de los vasos y se colocó en el centro de tiestos divididos en tres secciones. Cada sección tenía suelo al cual se le añadió cal a razón de $0,6.7$ ó $20 \mathrm{meq} / 100 \mathrm{~g}$. para conseguir un contenido de aluminio intercambiable equivalente a 10,4 y 0 meq. $/ 100$ g., respectivamente. En los otros dos métodos, secciones de semilla sembradas en envases plásticos o en cama de arena se colocaron en tiestos con un suelo al cual se le aplicá un nivel de cal, solamente. Al cabo de 18 días las raíces

'Submitted to Editorial Board February 22, 1989.

'Research Soil Scientist, USDA, ARS, TARS, Mayagùez, P. R. 00709.

${ }^{3}$ Research Assistant, Department of Horticulture.

'Research Plant Physiologist, USDA, ARS, TARS, Mayagüez, P. R. 00709.

sStatistician, USDA, ARS, Gainesville, FL. 
que penetraron cada sección, se cortaron y se clasificaron por tamaño. El crecimiento mayor de raíces ocurrió en la sección del tiesto que contenía suelo encalado a razón de $6.7 \mathrm{meq} .1100 \mathrm{~g}$.

\section{INTRODUCTION}

The objective of this investigation was to test three rapid methods for screening tanier (Xanthosoma spp.) root growth rates as a means of determining potential tolerance to acid soils.

Taniers are an important starchy root in the humid tropics. In Puerto Rico, yields of as high as $20,000 \mathrm{~kg} / \mathrm{ha}$ have been reported (4). Taniers are cultivated on widely diverse soils, including those considered of marginal value for other crops (3). One of the factors affecting tanier yield is soil acidity, but there is little published on its effects. Abruña et al. (1) reported that the Morada variety showed a moderate degree of tolerance. Yields fell to $60 \%$ of maximum as soil aluminum saturation increased to $50 \%$. Information on tolerance of taniers to high levels of soil aluminum would be useful for recommending appropriate varieties for acid areas. Because of the relatively long planting to harvest cycle of taniers (approximately 12 months), obtaining this information from field experiments is slow and costly. There is, therefore, interest in developing methods for more rapidly evaluating responses of tanier to soil acidity.

\section{MATERIALS AND METHODS}

\section{Propagating Material}

Corm sections from five plants each of the Alela (white) and Vinola (purple) varieties of tanier growing on a Coto soil (Tropeptic Haplorthox) were used as a source of propagating material. On 8 July, 1987, the corms were sliced into 10 disks $2.5 \mathrm{~cm}$ in thickness, which were then subdivided into halves with at least one undeveloped bud per section. The sections were left in the shade for 24 hours to suberize, then weighed, submerged in a $0.5 \% \mathrm{NaOCl}(10 \%$ commercial bleach) solution for 10 minutes, and rinsed in distilled water. The sections were then placed in a growth medium (sand or Pro-Mix).

\section{Soil}

The soil used for the experiment consisted of the top $90 \mathrm{~cm}$ of a Maricao clay (Dystropeptic Tropudults) collected from Indiera Fría in the northern part of the municipality of Yauco in southwestern P. R. After air-drying, sieving, and thorough mixing, batches of $2,500 \mathrm{~g}$ of soil were mixed with 20-20-20 "Nutrileaf" fertilizer sufficient to supply 157 $\mathrm{mg} / \mathrm{kg}$ each of $\mathrm{N}, \mathrm{P}_{2} \mathrm{O}_{5}$, and $\mathrm{K}_{2} 0$. Three liming treatments were established using powdered $\mathrm{Ca}(\mathrm{OH})_{2}$ (cal Florida) at 0,6.67 and 20 meq of $\mathrm{Ca}$ per $100 \mathrm{~g}$ soil. On 7 August 1987, distilled water was added to each plastic sack of soil to bring it to $93 \%$ of estimated field capacity $(0.388$ 
$\mathrm{g} / \mathrm{g}$ oven-dry soil). Three days later, the soil was remixed in each bag. For the $0,6.67$ and 20 meq/100 $\mathrm{g}$ lime treatments the $\mathrm{pH}$ measured in $0.01 \mathrm{M} \mathrm{CaCl}_{2}$ was $4.32,4.68$ and 6.77 , exchangeable $\mathrm{Ca}$ was $1.6,5.7$ and $17.8 \mathrm{meq} / 100 \mathrm{~g}$, exchangeable $\mathrm{Mg}$ was $2.2,2.2$ and $1.0 \mathrm{meq} / 100 \mathrm{~g}$, and exchangeable $\mathrm{Al}$ was $9.9,4.2$ and 0 meq/100 g, respectively.

\section{Method I}

Twenty-four pots $15 \mathrm{~cm}$ tall, $15 \mathrm{~cm}$ in diameter at the bottom and 20 $\mathrm{cm}$ in diameter at the top, were filled with soil from the three lime treatments. Corm sections previously planted in a sand bed were washed, and the roots (which were up to $30 \mathrm{~cm}$ long) wrapped around them. The sections were then placed in an open hole left in the soil-filled pots. The hole was lined with a single layer of nylon netting with openings $3 \mathrm{~mm}$ in diameter. We lined the hole with the netting by wrapping a piece of previously cut netting around an empty plastic cup $7.4 \mathrm{~cm}$ tall, $8.7 \mathrm{~cm}$ in diameter at the top and $5.1 \mathrm{~cm}$ at the bottom. We held the cup at the top of the pot while filling the pot with soil. When the pot was full, we removed the cup, leaving the netting in place in the soil. After we had placed the corm sections in the hole, soil was added around the section to ensure good contact.

\section{Method II}

Twenty-four pots were filled with soil that had received one of the three lime treatments. We prepared a hole lined with netting as described above. The tanier corm sections for this method were planted in Pro-Mix in the plastic cups previously described. The corm sections, roots, and the Pro-Mix in which they had been growing were removed from the plastic cups and placed in the hole as an undisturbed unit.

\section{Experimental Design}

A split plot design was used for Methods I and II. Variety was the main plot treatment and method and lime level were subplot treatments. There were four blocks according to greenhouse location and time of harvesting operations. Within a variety, plants for each of the four blocks came from the same corm. The plants were selected for uniformity based on initial corm section weight and shoot development rating attained at planting time.

\section{Method III}

Corm sections grown in cups of Pro-Mix were planted in pots containing all three lime levels. Twenty-four pots were symmetrically filled with soil from the three liming treatments placed in 3 plastic bags approximately $24 \mathrm{~cm}$ by $34 \mathrm{~cm}$ which had been slit open $10 \mathrm{~cm}$ above the base. Thus, the bottom 8 to $10 \mathrm{~cm}$ of the pot consisted of three "pie-shaped" wedges of soil held in individual plastic bags. The upper section of the 
pot also contained the three soil treatments, except that enough space was left unfilled to place the tanier plant in Pro-Mix. We placed the soils around a netting-lined plastic cup as previously described. The 24 Method III pots were arranged in a split plot design, with variety and block as main factors, and soil lime level as the split factor (three levels applied to each pot). The three pots per block-variety combination were statistically treated as multiple observations of one experimental unit.

After planting, distilled water was added to all the pots, which were kept in partial shade for 3 days. The pots were then transferred to a screened shelter, in which air temperatures ranged from $25^{\circ}$ to $38^{\circ} \mathrm{C}$.

Harvest

The plants were removed from the pots on August 31 after 18 days of growth. Roots growing outside the netting were cut off and separated from the soil and divided into categories by size: coarse (approximately 2 to $3 \mathrm{~mm}$ in diameter), intermediate (approximately $1 \mathrm{~mm}$ in diameter), and fine $(0.2$ to $0.3 \mathrm{~mm}$ in diameter). The lengths of the coarse and intermediate fractions were measured, and the oven-dry root fractions and tops were weighed.

Four additional pots, which were planted at the same time as those of the main experiment, were examined at 31 or 49 days after planting in order to evaluate the effects of increased growing time.

Evaluation of Effects of Solution Aluminum Levels on Root Growth

Six plants, three of each variety, which had been grown in Pro-Mix in plastic cups, were used for a solution culture study. The plants were transferred to plastic cups, the bottoms of which had been removed. Three roots from each plant were introduced into $300-\mathrm{ml}$ containers, one root per container. These containers were filled with $1 m M \mathrm{CaCl}_{2}$ solutions with varying concentrations of $\mathrm{Al}(0,0.012$, or $0.048 \mathrm{mM})$ added in the form of aluminum chloride. The $\mathrm{pH}$ of the solution was initially adjusted to 4.4. Root lengths were measured twice a week for 1 month.

\section{RESULTS AND DISCUSSION}

\section{Methods I and II}

The Shoot Dry Weight (SDW) for the Vinola plants tended to be heavier than that of the Alela plants $(2.02 \mathrm{~g}$ vs. $1.57 \mathrm{~g}$ significant at $\mathrm{P}$ $=0.10$ ), but there was no significant lime effect (table 1 ). SDW, affected by pre-transplant management, was higher in the Method I Pro-Mix cup procedure $(2.15 \mathrm{~g}$ vs $1.43 \mathrm{~g})$. This effect was already evident at planting time. The plants selected for the experiment which had been grown individually in Pro-Mix had a significantly higher shoot development (3.5) than the plants from the bed culture (2.5). There was a significant positive effect of section weight on SDW in the plants grown in Pro-Mix $(r=.616, P=.001)$; this was particularly evident in Alela, which had 
TABLE 1.-Analysis of variance of shoot dry weight (SDW), fine root dry weight (FRDW), and total root dry weight (TRDW) for Methods $I$ and II

\begin{tabular}{|c|c|c|c|c|c|c|c|}
\hline \multirow[b]{2}{*}{ Source } & \multirow[b]{2}{*}{$\mathrm{df}$} & \multicolumn{2}{|c|}{ SDW } & \multicolumn{2}{|c|}{ FRDW } & \multicolumn{2}{|c|}{ TRDW } \\
\hline & & $\begin{array}{l}\text { Mean } \\
\text { square }\end{array}$ & $\mathrm{F}$ & $\begin{array}{l}\text { Mean } \\
\text { square }\end{array}$ & F & $\begin{array}{l}\text { Mean } \\
\text { square }\end{array}$ & $F$ \\
\hline Variety (V) & 1 & 2.38 & 5.5 & 15 & 0.2 & 37 & 0.6 \\
\hline Blocks (B) & 3 & 0.69 & 1.6 & 1535 & $17.2^{; *}$ & 2191 & $36.0^{* * * ;}$ \\
\hline VB, error (a) & 3 & 0.43 & 1.7 & 89 & 0.3 & 61 & 0.1 \\
\hline Method (M) & 1 & 6.18 & $24.5^{* * 1}$ & 682 & 2.2 & 2187 & $5.0^{*}$ \\
\hline Lime (L) & 2 & 0.18 & 0.7 & 2944 & $9.4^{* * * * *}$ & 3082 & $7.0^{* * *}$ \\
\hline LM & 2 & 0.84 & $3.3^{*}$ & 1218 & $3.9^{*}$ & 1603 & $3.6^{*}$ \\
\hline VM & 1 & 0.10 & 0.4 & 295 & 0.9 & 533 & 1.2 \\
\hline LV & 2 & 0.88 & $3.5^{*}$ & 755 & 2.4 & 2186 & $5.0^{*}$ \\
\hline LMV & 2 & 0.12 & 0.5 & $1313^{*}$ & $4.2 *$ & 983 & 2.2 \\
\hline Error (b) & 30 & 0.25 & & 3.3 & & 441 & \\
\hline
\end{tabular}

$i *, * *, * * *=\mathrm{P}<0.05,0.01$, and 0.001 , respectively.

smaller sections (ranging from $23 \mathrm{~g}$ to $71 \mathrm{~g}$, vs $47 \mathrm{~g}$ to $97 \mathrm{~g}$ for Vinola). Enyi (2) observed similar effects when larger sections were planted. There was no effect of the location in the mother corm from which the individual section was taken.

Among the root variables there were significant differences in fine root dry weight (FRDW) and total root dry weight (TRDW) due to lime rates (table 1 ). The 0 and high lime treatment weights were lower than those with the intermediate lime rate (table 2). The highest rate (20 meq/100 g) raised the $\mathrm{H}_{2} \mathrm{O} \mathrm{pH}$ to 6.94 , which was well above the level necessary to precipitate the exchangeable Al. The resulting decreased growth may have been due to decreased availability of $\mathrm{Mg}$ or to deficiencies of $\mathrm{P}, \mathrm{B}, \mathrm{Zn}$ or $\mathrm{Mn}$ which can occur when highly-weathered soils are over-limed (5). There was no significant effect of variety. There were no effects of lime rate or variety in length of coarse roots (LCR), number of coarse roots, mean length per coarse root (LCR divided by number of coarse roots per plant), or dry weight of intermediate or coarse roots. There were significant effects of pre-transplant management on LCR and TRDW, but not on FRDW (table 2).

Corm, section location on the corm, section weight or shoot development rating did not significantly affect root growth.

\section{Method III}

The divided pot method had the advantage that roots from one individual plant grew into soil at all three $\mathrm{pH}$ levels. Lime had a significant effect on LCR, FRDW, and TRDW (table 3), but not on number or mean length of coarse roots, which were highly variable. Root growth in the soil segment receiving the intermediate lime treatment of $6.7 \mathrm{meq} / 100 \mathrm{~g}$ 
TABLE 2.-Effect of lime, variety and pre-treatment management on length of coarse roots (LCR), fine root dry weight (FRDW) and tolal root dry weight (TRDW) in Methods I and II

\begin{tabular}{|c|c|c|c|c|}
\hline \multicolumn{2}{|c|}{ Treatment } & LCR & FRWD & TRDW \\
\hline & & $\mathrm{cm}$ & - & $g-$ \\
\hline $\begin{array}{r}\text { Lime } \\
0 \\
6 . \\
20\end{array}$ & nce $(P)$ & $\begin{array}{r}1030 \\
1136 \\
963 \\
\mathrm{NS}\end{array}$ & $\begin{array}{r}43 \\
53 \\
26 \\
0.001\end{array}$ & $\begin{array}{r}59 \\
73 \\
45 \\
0.003\end{array}$ \\
\hline $\begin{array}{r}\text { Varie } \\
\text { Ale } \\
\text { Vir }\end{array}$ & nce $(P)$ & $\begin{array}{r}964 \\
1122 \\
0.104\end{array}$ & $\begin{array}{l}41 \\
40 \\
N S\end{array}$ & $\begin{array}{c}58 \\
60 \\
\text { NS }\end{array}$ \\
\hline $\begin{array}{c}\text { Meth } \\
\text { I } \\
\text { II }\end{array}$ & nce $(P)$ & $\begin{array}{r}858 \\
1228 \\
0.001\end{array}$ & $\begin{array}{c}37 \\
44 \\
\text { NS }\end{array}$ & $\begin{array}{r}52 \\
66 \\
.034\end{array}$ \\
\hline $\begin{array}{c}\text { Lime } \\
0 \\
6.7 \\
20 \\
0 \\
6.7 \\
20\end{array}$ & $\begin{array}{l}\text { Variety } \\
\text { Alela } \\
\text { Alela } \\
\text { Alela } \\
\text { Vinola } \\
\text { Vinola } \\
\text { Vinola }\end{array}$ & $\begin{array}{r}901 \\
1185 \\
806 \\
1159 \\
1087 \\
1121\end{array}$ & $\begin{array}{l}44 \\
60 \\
20 \\
42 \\
46 \\
33\end{array}$ & $\begin{array}{l}58 \\
84 \\
33 \\
59 \\
62 \\
58\end{array}$ \\
\hline \multicolumn{2}{|c|}{ CV (based on error (b)) } & $34 \%$ & $43 \%$ & $36 \%$ \\
\hline
\end{tabular}

$\left(\mathrm{H}_{2} \mathrm{O} \mathrm{pH}\right.$ 4.96) was greater than that in the unlimed soil segment $\left(\mathrm{H}_{2} \mathrm{O}\right.$ $\mathrm{pH} 4.64$ ) or the overlimed soil segment (table 4). The variety and variety by lime interaction effects were not significant for any of the root variables.

TABLE 3.-Split plot analysis of variance of length of coarse roots (LCR), fine root dry weight (FRDW) and total root dry weight (Method III)

\begin{tabular}{|c|c|c|c|c|c|c|c|}
\hline \multirow[b]{2}{*}{ Source } & \multirow[b]{2}{*}{$\mathrm{df}$} & \multicolumn{2}{|c|}{ LCR } & \multicolumn{2}{|c|}{ FRDW } & \multicolumn{2}{|c|}{ TRDW } \\
\hline & & $\begin{array}{l}\text { Mean } \\
\text { square }\end{array}$ & $F$ & $\begin{array}{c}\text { Mean } \\
\text { square }\end{array}$ & $F$ & $\begin{array}{l}\text { Mean } \\
\text { square }\end{array}$ & $F$ \\
\hline Blocks (B) & 3 & 61145 & 0.3 & 433 & 4.9 & 761 & 6.1 \\
\hline Variety (V) & I & 109356 & 0.6 & 105 & 1.2 & 27 & .2 \\
\hline BV, Error (a) & 3 & 179952 & & 89 & & 124 & \\
\hline Pots (B V) & 16 & 97239 & & 92 & & 130 & \\
\hline Lime (L) & 2 & 424236 & $4.0^{*-1}$ & 427 & $5.3^{*}$ & 755 & 5.2 \\
\hline LV & 2 & 7483 & 0.1 & 174 & 2.2 & 279 & 1.9 \\
\hline \multicolumn{8}{|l|}{$\mathrm{LB}+\mathrm{LBV}$, } \\
\hline Error (b) & 12 & 106725 & & 82 & & 145 & \\
\hline L Pots (B V) & 32 & 142859 & & 105 & & 199 & \\
\hline \multicolumn{8}{|l|}{ CV (based on } \\
\hline Error (b)) & & $73 \%$ & & $72 \%$ & & $63 \%$ & \\
\hline
\end{tabular}

$$
1 *=\mathrm{P}<0.05 \text {. }
$$


TABLE 4.-Effect of lime rates on coarse roots (LCR), fine root dry weight (FRDW) and total root dry weight (TRDW) in split pots (Method III)

\begin{tabular}{lccc}
\hline Treatment & LCR & FRWD & TRDW \\
\hline & $c m$ & & \\
$\mathrm{Ca}(\mathrm{OH})_{2}$ applied & & & \\
$\quad($ meq $/ 100 \mathrm{~g})$ & & & \\
0 & 430 & 16.1 & 13.6 \\
6.7 & 588 & 12.8 & 24.8 \\
20.0 & 324 & 0.023 & 0.023 \\
Significance of effect $(\mathrm{P})$ & 0.047 & & \\
Coefficient of variation & & $72 \%$ & $63 \%$ \\
18 days & $73 \%$ & $63 \%$ & $58 \%$ \\
31 and 49 days & $113 \%$ & & \\
\hline
\end{tabular}

The increase in root growth in the intermediate lime treatment soil was more marked in Method III than in Methods I and II. One explanation is that in the split pots the plants had access to all three levels of soil $\mathrm{pH}$, and root growth was proportionally more vigorous in the soil with the most favorable conditions.

We examined the lime response in an alternative way in order to determine the lime response on an individual plant basis. We calculated a per-plant lime response ratio (LRR) by dividing the amount of root found in the zero lime treatment by the sum of the amounts found in the zero and intermediate treatments. By definition, the LRR was less than 0.5 in those pots where there was an improvement because of lime addition at the intermediate level. A $t$-test analysis of these ratios for TRDW and FRDW showed that they were significantly smaller than 0.5 , and thus that there was a significant positive response to lime (table 5). Using LRR, we tested for differences among varieties in their response to lime, but no significant difference between varieties was detected.

\section{Effects of Longer Growth Periods}

We studied the possibility that growing the plants longer might reduce variability, based on the assumption that error-contributing chance factors would become relatively less important as the total amount of root material increased. Roots were analyzed in four extra Method III pots that were allowed to grow for 31 days and 49 days. For FRDW and

TABLE 5.-Lime response ratio for length of coarse roots (LCR), fine root dry weight (FRDW) and total root dry weight (TRDW) for two varieties (Method III)

\begin{tabular}{lccc}
\hline Variety & LCR & FRDW & TRDW \\
\hline Alela & 0.35 & 0.38 & 0.38 \\
Vinola & 0.43 & 0.32 & 0.37 \\
Significance of variety effect & NS & NS & NS \\
\hline
\end{tabular}


TRDW, there was a small decrease in the coefficient of variation (CV) as compared to the $\mathrm{CV}$ found in the roots growing in the 18-day pots, but the variability in LCR increased (table 4).

\section{Solution Study}

In order to obtain information on whether the detrimental factor reducing root growth was aluminum, we studied root growth by using solution cultures with $1 \mathrm{mM}$ Ca as calcium chloride and $0,0.012$ or 0.048 $m M \mathrm{Al}$ as aluminum chloride.

Root growth rate during the 4-week period was almost constant, decreasing slightly with time. Average root growth rate was calculated on the basis of the difference between root lengths on the first and the 28th day of growth. Four of the roots broken or damaged before the 28th day were treated as missing values in the statistical analysis. Vinola mean root growth rate $(10.9 \mathrm{~mm} /$ day $)$ was significantly greater than that of Alela (7.9). The mean growth rate in the $0.048 \mathrm{mM}$ Al solution was 6.3 $\mathrm{mm} /$ day, which was significantly less than the mean 11.0 and $10.9 \mathrm{~mm} /$ day growth rates in the 0 and $0.012 \mathrm{mM} \mathrm{Al}$ solutions. No significant difference in variety response to aluminum was detected in this experiment.

The marked decrease in growth due to aluminum in the solution culture indicates that aluminum may have been the principal toxic factor in the acid soil used in this study.

\section{CONCLUSIONS}

Of the methods evaluated for detecting differences in response to soil acidity, the best seemed to be transplanting into split pots, using prerooted tanier sections that had been grown in Pro-Mix in individual cups. The least desirable method was growing all the plants together in a sand bed in the pre-transplant stage. Both root and top growth in this method were less.

Total root dry weight and fine root (diameter less than $0.3 \mathrm{~mm}$ ) dry weight seemed to be more responsive to soil $\mathrm{pH}$ than length of coarse roots (diameter greater than $2 \mathrm{~mm}$ ), dry weight of intermediate roots or number or mean length of coarse roots. There were positive responses to the addition of $6.67 \mathrm{meq} / 100 \mathrm{~g} \mathrm{Ca}(\mathrm{OH})_{2}$ which raised the $\mathrm{H}_{2} \mathrm{O} \mathrm{pH}$ from 4.64 to 4.96 . The addition of $20 \mathrm{meq} / 100 \mathrm{~g} \mathrm{Ca}(\mathrm{OH})_{2}\left(\mathrm{H}_{2} \mathrm{O} \mathrm{pH} 6.94\right)$ reduced root growth. The two varieties chosen for this experiment responded similarly to liming.

Coefficients of variation ranged from 34 to $73 \%$. A recommendation to reduce variability is to use more mother corms. This would provide more corm sections to choose from than were available in the present experiment, so that those used would be more uniform in terms of section weight and state of shoot development at transplanting. Corm sections should weigh at least $50 \mathrm{~g}$. 


\section{LITERATURE CITED}

1. Abruña-Rodriguez, F., J. Vicente-Chandler, E. Rivera and J. Rodriguez, 1982. Effect of soil acidity factors on yields and foliar composition of tropical root crops. Soil Sci. Soc. Am. J. 46 (5): 1004-007.

2. Enyi, B. A. C., 1967. Effect of spacing, sett size, ridging and mulching on the development and yield of cocoyam (Xanthosoma sagittifolium (L) Schott). Trop. Agric. (Trinidad) 44 (1): 53-60.

3. Plucknett, D. L., 1978. Tolerance of some tropical root crops and starch-producing tree crops to suboptimal land conditions in Jung, G. A. (Ed), Crop Tolerance to Suboptimal Land Conditions. ASA Special Publication No. 32: 125-144. American Society of Agronomy, Madison, Wisconsin.

4. Rodríguez-García, J., F. Abruña and N. Díaz, 1981. Effect on tanier yields of artificial shade trees and of intercropping with plantains. J. Agric. Univ. P. R. 65 (4): 326-30.

5. Sánchez, P. A., 1976. Properties and Management of Soils in the Tropics. John Wiley and Sons, New York. 